\title{
Possibility of Identifying the Logical-Mathematical Giftedness with Students of Lower Primary School Grades through Evaluations
}

\author{
Sanja Milić ${ }^{1} \Varangle$ \\ Vlado Simeunovićc \\ ${ }^{2}$ Faculty of Education Bijeljina, University of East Sarajevo, Bosnia and Herzegovina \\ Email:sanja.milic@pfb.ues.rs.ba Tel: +38765802494 \\ Email:vlado.simeunovic@pfb.ues.rs.ba Tel: +38765926909
}

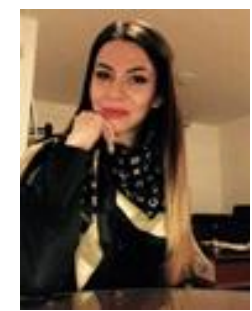

( Corresponding Author)

\begin{abstract}
The objective of this work is examination of co-ordinance amongst assessments of logicalmathematical giftedness with young primary school students, made by four groups of evaluators: teachers, parents, coevals and self-evaluators. Teachers of 11 primary schools selected at the area of Republic Srpska were assigned to follow Instructions for Nomination and select most capable students of Years Three and Four, who would be directly involved in the research. An evaluation of logical-mathematical giftedness was performed on a sample of 151 named students, using an instrument created for the needs of this research. The results have shown a high level coordinance in evaluation of logical-mathematical giftedness between teachers and students and between parents and coevals, which leads to a conclusion that there is a scientific justification to innovate the teaching process while working with gifted students at primary schools, by applying a questionnaire developed for evaluation of logical-mathematical giftedness to be done by teachers, parents, students and coevals. This work allows a space for forming data bases on evaluations of students' abilities, in order to plan the next step which would be creating a predictive model based upon likelihood and expectations as to the possibility of identifying giftedness.
\end{abstract}

Keywords: Gifted students, Identifying the giftedness, Multiple intelligences, Logical-Mathematical intelligence, Evaluation.

Citation | Sanja Milić; Vlado Simeunović (2017). Possibility of Identifying the Logical-Mathematical Giftedness with Students of Lower Primary School Grades through Evaluations. Journal of Education and e-Learning Research, 4(4): 154-162.

History:

Received: 7 November 2017

Revised: 28 November 2017

Accepted: 1 December 2017

Published: 6 December 2017

Licensed: This work is licensed under a Creative Commons

Attribution 3.0 License (cc) BY

Publisher:Asian Online Journal Publishing Group
Contribution/Acknowledgement: Both authors contributed to the conception and design of the study.

Funding: This study received no specific financial support.

Competing Interests: The authors declare that they have no conflict of interests.

Transparency: The authors confirm that the manuscript is an honest, accurate, and transparent account of the study was reported; that no vital features of the study have been omitted; and that any discrepancies from the study as planned have been explained.

Ethical: This study follows all ethical practices during writing.

\section{Contents}

1. Introduction

Q. Method

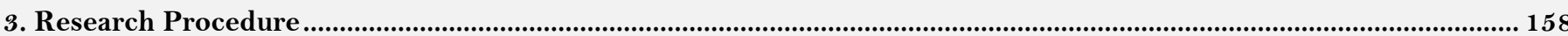

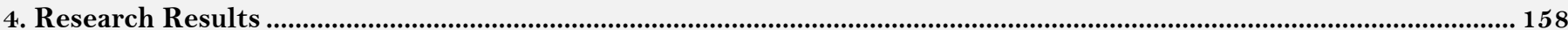

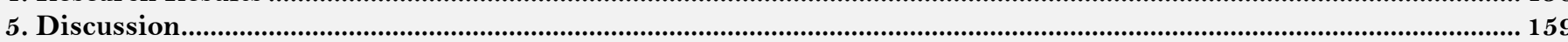

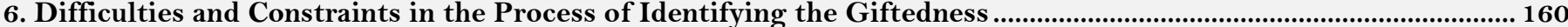

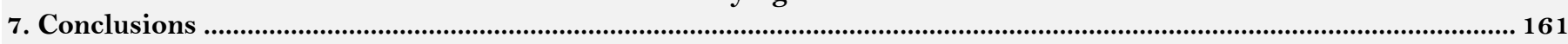

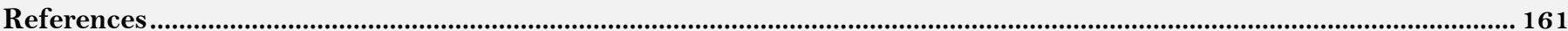




\section{Introduction}

In order to improve the achievements in identifying and developing the potentials of the gifted, it is necessary to innovate the methods, procedures and instruments, as well as the approaches to determining the existence, structure and extent of giftedness, in accordance with achievements of other sciences dealing with studies of humans. A recent study shows that the identification itself is still one of most analysed topics in scientific literature relevant to education of the gifted (Dai et al. (2011); see at: McBee et al. (2014)).

Modern approaches to giftedness imply inclusion of a large number of factors into the process of identifying giftedness with students, but also their active participation in their development and social promotion. Thus, many authors (Callahan et al., 1995; Han and Marvin, 2000) suggest taking into consideration the following recommendations for a successful identification process: to select and follow a clear definition of giftedness, to avoid using only one limit value, to consider more than one form of manifestation of giftedness, to apply various instruments for evaluation of different types of intelligence, to bear in mind that giftedness shows in different forms, to develop a basis for educational needs of students following the identification, to carry out a repeated evaluation after certain time in order to determine whether there are more of gifted students.

The selection of methods and procedures for identifying the giftedness depends on the method of approaching and interpreting it. It is very important to have a close connection between the conception of giftedness, characteristics of the gifted, their identification, and the curricula intended for such population (George, 2005).

Mezö (2008) has performed a deep analysis of the issue of identifying giftedness, and derived the key questions representing a standpoint of planning and implementing the identification process itself. Some of these questions are the following: What components form the concept of giftedness? What is the best method of confirming the existence of giftedness? What is the most appropriate procedure for identifying gifted students? Where is the limit of giftedness to be set at standardised instruments? Should the subjective or objective methods be selected? (Mezö, 2008).

Researches show that many gifted children do not become particularly successful in the course of further development in their lives. A question is then asked - why is that so? A number of countries have attempted to solve the issue of identifying gifted children through their system, and to apply programmes designed to influence a development of their potentials during their childhood, with the objective for their development to become a result of their inner needs for attaining knowledge and a reflection of their manifestation interests. As of 2009, 41 out of 47 surveyed countries have reported to have a formal definition of giftedness (NAGC, 2009; see: McBee et al. (2014)). Within these (41) countries, most frequent areas included in giftedness were intellectual abilities, creativity, visual arts, specific academic abilities and leadership, and only 29 countries require using the same definition by all local educational agencies. Namely, the criteria needed for identifying giftedness vary from one country to another or even from one educational district to another, which makes a comparison impossible. This phenomenon is sometimes called "geographical giftedness" (Borland, 1989).

At the area of Republic Srpska, there are no such programmes which systematically deal with the issues of giftedness and development of abilities in gifted students (Simeunović and Milic, 2013). Legal requirements were defined only recently, and responsibilities of institutions for such type of activities were then stipulated. The identification should, according to George (2005) be more widespread considered a part of good quality teaching: a permanent process where more challenging learning experiences are required, to result in a good quality final product. Such approach to the identification is an evolutional process rather than a set of tests. Best possible practice in detecting gifted and talented students is making decisions based upon several measurements (McBee $e t$ al., 2014).

In the process of identifying gifted individuals, two main procedures are conducted: the testing procedure and assessment procedure. High costs of testing lead to reluctance to such procedure, thus most gifted and creative students pass through their education unnoticed (Simeunović and Milic, 2013). Therefore the procedure of assessment is exceptionally significant in recognising students' abilities.

Although assessments of potentials of giftedness are mainly subjective by their nature and therefore prone to errors, gathering information on students by teachers, parents, coevals, psychologists, pedagogists, principals, as well as information obtained based on self-evaluation, are exceptionally valuable in detecting and directing students' creative abilities.

Multiple intelligences tend to be more frequently applied in assessment of giftedness internationally (Gardner, $1985 ; 1993 ; 1999 ; 2003 ; 2006)$ thus there are appropriate recommendations for use of various instruments depending on certain types of abilities (Bordelon and Banbury, 2005; Chan, 2007; Tirri and Nokelainen, 2008; HernándezTorrano, 2014).

The basis for this research are the results of work of Howard Gardner, published in the books Frames of Mind (1983), Multiple Intelligences (1993) and Multiple Intelligences for the 21 $1^{\text {st }}$ century (1999), Multiple Intelligences, Nere Horizons (2006), as well as work results of Thomas Armstrong, one of the best interpreters of Gardner's theory of multiple intelligences, published in the book Multiple Intelligences in the Classroom (2006).

\section{Method}

Objective and hypotheses of the research. The aim of this work is to examine a co-ordinance amongst evaluations of logical-mathematical giftedness in young primary school students, done by four groups of evaluators: teachers, parents, coevals and students themselves.

Since the research findings, published internationally and in our country (Đorđević, 1998; Bordelon and Banbury, 2005; Chan, 2007; Tirri and Nokelainen, 2008; Hernández-Torrano, 2014; Simeunović and Milić, 2014) on the issue of identifying and evaluating the giftedness, have shown significant connections between compared results obtained through different procedures of detecting giftedness, the main and initial hypothesis of the research is an existence of co-ordinance in evaluation of logical-mathematical intelligence, performed by various evaluators 


\subsection{Research Sample}

Since there are no records on gifted students and these are pioneering attempts of identifying the giftedness at this area, statistic estimates of possible participation of gifted students within the entire school children population were the standpoint for sampling process. Total population of Year Three and Four students in academic year 2013/2014 was 20,925; out of what 10,364 were in Year Three, and 10,561 in Year Four. As abilities have the form of Gauss Curve, and above average students have Intelligence Coefficient of over 110 according to Cattel Scale, total population of potentially gifted students takes the area underneath the Curve of normal distribution of $+1 \sigma$, i.e. $15.8 \%(13.6+2.2)$ which is 3,306 students.

Number of students who underwent this research is 151 , which is $5 \%$ of total population of (theoretically) gifted students. Considering this low level representation within general population, it is clear that this sample has been adjusted but sufficiently representative as well.

\subsection{Sample Structure Based on Schools}

The research included 11 primary schools located in the Republic of Srpska at its three regions: Zvornik, Bijeljina and Romanija.

Table-1. Sample Structure According to Schools

\begin{tabular}{l|l|l}
\hline School & Frequencies & Percentage \\
\hline Primary School "Sveti Sava“, Crnjelovo & 10 & 6.6 \\
\hline Primary School "Vuk Karadžić, Bijeljina & 15 & 9.9 \\
\hline Pr. School “Knez Ivo od Semberije“, Bijeljina & 31 & 20.5 \\
\hline Primary School "Mesa Selimovic“, Janja & 20 & 13.2 \\
\hline Primary School "Jovan Ducic“, Bijeljina & 18 & 11.9 \\
\hline Primary School "Sveti Sava“, Zvornik & 9 & 6 \\
\hline Primary School "Sveti Sava“, Bijjeljina & 10 & 6.6 \\
\hline Pr. School "Stevan Nemanja“, Gornji Dragaljevac & 9 & 6 \\
\hline Pr. Sch. "Petar Petrovic Njegos“, Velika Obarska & 6 & 4 \\
\hline Primary School 'Petar Kocic“, Kozluk & 4 & 2.6 \\
\hline Primary School "Sokolac“, Sokolac & 19 & 12.6 \\
\hline Total & 151 & 100 \\
\hline
\end{tabular}

Most of the schools are in Bijeljina and its surroundings because it was simple for the researcher to perform the research at the area which is in their immediate vicinity, but also because of the largest population and number of schools there. To avoid the results to be relevant to Bijeljina only, the research was also conducted in Zvornik and Sokolac, as towns with largest population thus largest number of students in their regions. Having covered three regions and eleven schools (both town and village ones), the sample of the research became sufficiently representative and research results relevant.

\subsection{Structure of the Sample of Named Students}

Certain number of students considered by teachers and expert team to have above average abilities was named at each school proportionally to total number of students in Years Three and Four. The instructions for nomination of gifted students were given based upon the Ranking List of characteristics of most capable students according to teachers (Đorđević, 1998) which consists of the following factors: they are hard-working and attentive in classes, they understand the contents easily, they have their opinions on certain topics, they have good ideas, they have a good memory, they are quick in their work and study, they study regularly, they learn other things easily, they know a lot beyond the curriculum, they know how to organise their time, they can manage things easily, and they are capable of anything. Additional nomination of students achieving extraordinary results in arts and sport was required.

Table-2. Structure of selected students' sample

\begin{tabular}{l|l|l|l}
\hline \multicolumn{2}{l}{ Social-Demographic Characteristics } & Frequencies & Percentage \\
\hline \multirow{4}{*}{ Gender } & Male & 69 & 45.7 \\
\cline { 2 - 4 } & Female & 82 & 54.3 \\
\cline { 2 - 4 } & Total & 151 & 100 \\
\hline \multirow{3}{*}{ Year } & Three & 80 & 53 \\
\cline { 2 - 4 } & Four & 71 & 47 \\
\cline { 2 - 4 } & Total & 151 & 100 \\
\hline
\end{tabular}

It is noticeable that there are girls and boys among the selected students, but that there is a slightly larger number of girls. This fits into many researches which have confirmed that gifted girls are identified easier since they work harder and are more dedicated to their work than boys (Đorđević, 1998).

\subsection{Structure of Teacher Evaluator Sample}

Teachers who selected the students and then evaluated their giftedness are their class teachers. Since this is about lower grades where one teacher spends the whole work day with the same students, the duration of work in certain class was not particularly considered. It happened that one teacher evaluated two students, but this was treated as two evaluations. Generally, the teachers who performed evaluation have significant teaching experience. 
Table-3. Structure of the sample of teacher evaluators

\begin{tabular}{l|l|l|l}
\hline Social-Demographic Characteristics & Frequencies & Percentage \\
\hline \multirow{4}{*}{ Gender } & Male & 24 & 15.9 \\
\cline { 2 - 4 } & Female & 127 & 84.1 \\
\cline { 2 - 4 } & Total & 151 & 100 \\
\hline \multirow{4}{*}{ Years of Work } & Up to 10 years & 76 & 50.3 \\
\cline { 2 - 4 } & Over 10 years & 75 & 49.6 \\
\cline { 2 - 4 } & Total & 151 & 100 \\
\cline { 2 - 4 } & Secondary & 5 & 3.3 \\
\hline \multirow{4}{*}{ Qualifications } & College & 14 & 9.3 \\
\cline { 2 - 4 } & University & 132 & 87.4 \\
\cline { 2 - 4 } & Total & 151 & 100 \\
\hline
\end{tabular}

Most of the teachers are female, with up to ten years of work experience and with university degree. This information reveals the fact that the vocation of a grade teacher is very popular as a professional choice, primarily with young women.

\subsection{Structure of Parent Evaluator Sample}

In the course of research preparation, students and teachers were told to choose the parent who is higher educated for the purpose of evaluation, due to the assumption that their knowledge is more comprehensive and deeper, and that they had had the opportunity to learn more about the phenomenon of giftedness in the course of their education. A research (Biro, 1997) relevant to examination of metric characteristics of REWISC has also confirmed the influence of parents' education on children's success in a test.

Table-4. Structure of parent evaluator sample

\begin{tabular}{l|l|l|l}
\hline \multicolumn{2}{l|}{ Social-Demographic Characteristics } & Frequencies & Percentage \\
\hline \multirow{4}{*}{ Gender } & Male & 58 & 38.4 \\
\cline { 2 - 4 } & Female & 93 & 61.6 \\
\cline { 2 - 4 } & Total & 151 & 100 \\
\hline \multirow{2}{*}{ Qualifications } & Secondary & 91 & 60.3 \\
\cline { 2 - 4 } & College \& University & 60 & 39.7 \\
\cline { 2 - 4 } & Total & 151 & 100 \\
\hline
\end{tabular}

The sample structure shows that mainly mothers performed the evaluation, and that most of the parents of potentially gifted students have secondary school education.

\subsection{Structure of Coeval Evaluator Sample}

Coevals who evaluated the abilities were those students who, according to teachers, spent most time with the selected students, or to phrase it in a popular way those were their best class friends.

Table-5. Structure of coeval evaluator sample

\begin{tabular}{l|l|l|l}
\hline Social-Dem. Characteristics & Frequencies & Percentage \\
\hline \multirow{4}{*}{ Gender } & Male & 64 & 45.7 \\
\cline { 2 - 4 } & Female & 87 & 54.3 \\
\cline { 2 - 4 } & Total & 151 & 100 \\
\hline \multirow{4}{*}{ Year } & Three & 80 & 53 \\
\cline { 2 - 4 } & Four & 71 & 47 \\
\cline { 2 - 4 } & Total & 151 & 100 \\
\hline
\end{tabular}

When the structure of coeval sample and selected students are compared, it is noticeable that girls mainly evaluated other girls and the same with boys.

\subsection{Variables}

For the needs of evaluation of logical-mathematical giftedness, a comprehensive questionnaire was developed a scaler for teachers, parents, coevals and self-evaluation. In the course of structuring the items, the initial point was Gardner's definition of logical-mathematical intelligence, which points out that logical-mathematical intelligence is connected with the quickness in and power of abstract reasoning, the ability of finding remote connections and relationships between items and ideas (Gardner, 1985) it also implies the ability of recognising the patterns, then of operating with abstract symbols, noticing hidden connections and mutual relations between given data, as well as comprehending the essence of a problem and finding the ways of solution thereto easily. The instrument created for evaluation of this type of intelligence contains items which cover four domains of logicalmathematical intelligence: mathematical abilities, inductive and deductive reasoning, strategies of solving problems, as well as motivation.

\subsection{Instruments}

For the needs of evaluation of logical-mathematical intelligence, a comprehensive questionnaire - scaler was developed for all of the evaluator groups, containing 15 particles in the form of statements. The instrument consists of four scalers, out of which one is intended four each evaluator group. The assignment of the evaluator is to evaluate its agreement on each statement at the five-degree scale Likert type. Interpretation of the scale which is used for evaluation of the extent of logical-mathematical intelligence development has been organised in ascending 
order: 1 - strongly disagree, 2 - disagree, 3 - neutral, 4 - agree, 5 - strongly agree. All of the statements have been phrased as positive, and total result is expressed as a sum of each individual scale.

The reliability thereof has been determined applying the method of internal consistence, and expressed by the Cronbach's $\alpha$ coefficient.

Table-6. Reliability of the scales for evaluation of logical-mathematical intelligence

\begin{tabular}{l|l}
\hline Instruments & Cronbach alpha \\
\hline Scales for teachers & 0.884 \\
\hline Scales for parents & 0.873 \\
\hline Scales for coevals & 0.904 \\
\hline Scales for self-evaluation & 0.910 \\
\hline
\end{tabular}

The Cronbach's alpha coefficients obtained demonstrate a good and high-level internal consistence of the instrument.

\section{Research Procedure}

The research was conducted in the first half of 2015 in four phases. The first phase which included structuring the instruments lasted throughout the year of 2014, but the instruments were finally formed at the beginning of 2015. In the course of structuring the items, initial points were all of the nine variables of Gardner's definition. Several corrections and amendments were made in collaboration with experts in scientific and artistic fields the variables were relevant to. Thereupon, a pilot research was done at three schools on a sample of 15 examinees, seven of them of the third grade and eight of the fourth, for all of the four groups of evaluators, aiming to identify possible difficulties and constraints as to applying the instruments, i.e. a need for additional clarification of the instruments structured. The subjects were then tested in the field, through deep interviews, where the examinees provided feedback on question forms and clearness of the contents. The pilot research showed that there was no need for additional clarification in using the instruments and that the items were clear to all evaluator groups.

The aim of the second phase was establishing cooperation with schools. Since the work is a part of the project dealt with by Bijeljina Faculty of Teacher Education, financially supported by Ministry of Science and Technology, cooperation with schools was satisfactory to a high level. School principals received a request for cooperation, as well as an approval issued by Teacher-Expert Council of the Faculty of Teacher Education, for implementation of the Project one segment of which is subject matter of this research. Out of 11 schools which received the request, only one school refused cooperation for unknown reasons. Most of the participants accepted the research voluntarily and completed their part of the assignment within given time. Parents were informed of the objective and method of research in which they were involved. Children whose parents had not agreed on participation in the research were excluded from the observation. 180 packages of work material were received and 151 of them returned.

In the third phase, samples were to be formed. School principals who had accepted the cooperation were interviewed. Each school was visited separately. At that occasion, all of the teachers working with third and fourth grades were given instructions based on which they selected potentially gifted students. The teachers used the characteristics given in selection of students who were potentially gifted in teachers' opinions, whereupon they worked together with pedagogists in choosing certain number of most successful ones.

The fourth phase was the most complex one, and it related to evaluation of giftedness through the instruments created. Four groups of evaluators evaluated the presence of the characteristics in a named student at the scaler. The research was being performed for three days at one school. The first day the researcher organised a group evaluation to be done by coevals in duration of two school lessons, and the second day self-evaluation was performed. Both groups were given detailed instructions. The third day, evaluation was done together with teachers and parents.

\section{Research Results}

According to the criteria set for reading the degree of presence of certain intelligences, the results obtained in the scales were grouped in four intervals. Total number of those students who were, according to the criteria given beforehand, characterised as gifted in the area of logical-mathematical giftedness, is shown in Table 7 .

Table-7. Number of students categorised in accordance with presence of logical-mathematical giftedness according to evaluator groups

\begin{tabular}{l|l|l|l|l}
\hline Evaluators & $15-29$ & $30-44$ & $45-59$ & $60-75$ \\
\hline Teachers & 0 & 18 & 63 & 70 \\
\hline Parents & 1 & 26 & 87 & 37 \\
\hline Coevals & 1 & 31 & 67 & 52 \\
\hline Students & 0 & 22 & 62 & 67 \\
\hline
\end{tabular}

The first data indicate that evaluations made by all of the four evaluator groups led to the same direction. Normality of data distribution was checked applying the Kolmogorov-Smirnov and Shapiro-Wilk procedures, where the significance obtained was $p=0.066$ in the first and $p=0.062$ in the second procedure. Since the value obtained in both cases was $\mathrm{p}>0.05$, the distribution is normal. Levene statistics was 6.91 and it showed the significance at the level of 0.649 , which proves the homogeneity of the variance.

The co-ordinance amongst the evaluations as to logical-mathematical giftedness was tested applying the ANOVA and it showed that there were statistically significant differences among the four evaluator groups. 
Table-8. ANOVA - Co-ordinance amongst evaluations of logical-mathematical giftedness

\begin{tabular}{|c|c|c|c|c|c|c|c|c|}
\hline Dependent Variable & Groups & $\mathbf{A S}$ & SD & $\min$ & $\max$ & df & $\mathbf{F}$ & p \\
\hline \multirow{4}{*}{$\begin{array}{l}\text { Logical- } \\
\text { Mathematical } \\
\text { Giftedness }\end{array}$} & Teachers & 57.03 & 9.48 & 33 & 73 & \multirow[t]{4}{*}{3} & \multirow[t]{4}{*}{4.90} & \multirow[t]{4}{*}{.002} \\
\hline & Parents & 53.63 & 8.81 & 24 & 71 & & & \\
\hline & Coevals & 54.01 & 10.63 & 29 & 75 & & & \\
\hline & Students & 56.66 & 10.11 & 31 & 74 & & & \\
\hline
\end{tabular}

From the arithmetic mean and significance of the value $\mathrm{F}$ obtained, it is clear that the teachers evaluated the logical-mathematical intelligence highest, whereas parents' evaluations were the lowest. The results presented cannot show the exact ratio between variables, which is why Scheffe test was carried out to enable comparison at the level of a pair, as well as other comparisons available.

Table-9. Scheffe test of multiple comparisons between groups - Logical-Mathematical Giftedness

\begin{tabular}{l|l|l|l}
\hline \multicolumn{1}{c|}{$\begin{array}{c}\text { Evaluator } \\
\mathbf{I}\end{array}$} & $\begin{array}{c}\text { Evaluator } \\
\mathbf{J}\end{array}$ & $\begin{array}{l}\text { The difference between } \\
\text { arithmetic means (i-j) }\end{array}$ & $\mathbf{P}$ \\
\hline Teachers & Parents & $3.40397^{*}$ & .028 \\
\hline & Coevals & 3.01987 & .066 \\
\hline & Students & .37748 & .990 \\
\hline Parents & Teachers & $-3.40397^{*}$ & .028 \\
\hline & Coevals & -.38411 & .990 \\
\hline & Students & -3.02649 & .065 \\
\hline Coevals & Teachers & -3.01987 & .066 \\
\hline & Parents & .38411 & .990 \\
\hline Students & Students & -2.64238 & .138 \\
\hline & Teachers & -.37748 & .990 \\
\hline & Parents & 3.02649 & .065 \\
\hline & Coevals & 2.64238 & .138 \\
\hline
\end{tabular}

The results show that there is a statistically relevant difference between evaluations done by teachers and parents, while the highest-level co-ordinance was found between teachers and students, then parents and coevals.

\section{Discussion}

Selection of most capable students done by teachers is a most frequently applied procedure of identifying the giftedness (McBride, 1992) which is due to the fact that the gifted have a number of cognitive, motivational and personal characteristics which cannot be quantified applying standard tests. Meta-analysis presented in the Study on Teachers' Accuracy in the Identification of Gifted Children, Gear (1976) states that the accuracy ranges between $4.4 \%$ and $48 \%$. McBride (McBride, 1992) states that the reason for such minor accuracy is an insufficient training of teachers as to characteristics of gifted students. Borland (1989) thinks that the accuracy of teachers' nominations could be improved by directing their attention to familiarising with individual characteristics of gifted students, therefore researchers need to aim to develop instruments containing exact characteristics which distinguish gifted students ((Feldhusen et al., 1990; Davis and Rimm, 2004) see: Aljughaiman and Usama (2009)).

Results have shown an existence of statistically relevant difference $(F=4.90 ; p=0.002)$ between evaluations done by four evaluator groups. In this particular case, teachers evaluated the logical-mathematical giftedness highest $(\mathrm{AC}=57.03)$, while the parents made the lowest evaluations $(\mathrm{AC}=53.63)$. Students' own evaluation $(\mathrm{AC}=56.66)$ and coevals' evaluation $(\mathrm{AC}=54.01)$ are slightly lower than teachers'. The same results were obtained by Hernández and his associates (Hernández-Torrano, 2014). In the research (Simeunović and Milić, 2014) the results are similar, only students" self-evaluation was slightly higher than teachers' evaluation, whereas parents' evaluations were lowest. Research findings (Sommer et al., 2008) show that teachers evaluated intellectual abilities higher than parents, which can be an indicator of consistence of the data presented.

In the course of interpreting the results obtained, one obvious and worrying detail has emerged. Namely, if maximum score in the scale is 75, why was logical-mathematical giftedness evaluated this low by all of the four evaluator groups? The dilemma primarily arises from the teacher's low evaluation $(\mathrm{AC}=57.03)$. Why did the teachers select intelligent students, and evaluate them this low afterwards? If we neglect those who were selected for non-academic success (physical or music abilities), and there were few of them, what has happened to those who are academically gifted? One of the explanations could be that these low evaluations done by teachers resulted from their comparison to previous generations who had been more superior. It is quite possible that teachers with longer work experience had opportunities to work and learn together with students who do not belong to the information technology era where everything is given in its final shape, but to the time when there was more of learning, exploring and thinking. Truly talented students express their talents continuously, mostly through good intuition, quick reasoning at solving their tasks, various sorts of rationalisations of the solution and original ideas for solving thereof, which a teacher has seldom encountered in their teaching practice.

The results obtained through Scheffe test of multiple comparisons (Table 9) show that there is a statistically relevant difference between teachers and parents $(\mathrm{p}=0.028)$, but with highest-level co-ordinance between teachers and students $(\mathrm{p}=0.990)$, then parents and coevals $(\mathrm{p}=0.990)$. A discussion of results obtained as such suggests again a comparison of students' abilities within their coeval group. Since the most intelligent students in their classes were selected, teachers were expected to evaluate this field of giftedness highest, because it is common at local schools and in the society to equalise it with intelligence as such. Teachers frequently base their evaluation of various students' abilities on their success in certain subjects, as well as on comparison of results within one class. Data received from teachers are not necessarily reliable, since teachers can have different attitudes towards behaviour of gifted students (Freeman, 2005) but they are valuable elements for multi-dimensional approach to the identification of gifted students. 
Students who potentially have this type of intelligence were also rather modest in assessment of their power, which can be seen from their evaluations. Researches show (Dweck and Leggett, 1988) that intelligent persons are prone to underestimate themselves and those less intelligent to overestimate their abilities. This statement is certainly relevant to gifted population only. Although self-evaluation depends on a number of factors, such as personality, emotions, relationships with the environment; it enables gifted students to assess their own abilities, knowledge, skills and habits, then to undertake a responsibility for their learning process; and teachers and parents are thereby given signals that they need to react accordingly. Lubart (1994) points out possible mistakes implied in self-evaluation, stating that people can be either too modest or boastful while evaluating themselves; they can also forget certain achievements, as well as fail to consider an achievement creative whereas other people would certainly think of it as such.

Similarity in parents' and coevals' evaluations, which differ from teachers' and students' evaluations, can be explained by the fact that neither parents nor coevals have sufficient knowledge on children's thinking to assess it accurately, but they form their opinion based on the opinion of the social environment which always ranks the student with precision. Parents generally made very low evaluations in this research, but they also made large intervals of variations, where the evaluation ranged between minimum 24 and maximum 75 . It had not been expected from parents, who are generally subjective and prone to glorify a success of their children, to make such low evaluations in the area of logical-mathematical giftedness particularly.

Reason for such high level of result dispersion can be sought in different degrees of knowledge as to basic characteristics of logical-mathematical intelligence, but also of their abilities to detect the behaviour pattern which suggests presence of said intelligence. At the same time, realistic versatility of students in manifestation of given characteristics and in making creative products could be a reason for such dispersion. This is encouraging at certain level, since small dispersions can reflect evaluator's tendency to averaging. The advantage of parents' evaluation is the fact that no one else has more information about the child, as well as that they can observe their child continuously and notice its behaviour and achievements in various situations. However, information obtained from a parent should be dealt with cautiously, since they are not able to be objective in most cases. One-sided inclination and positive biasness in evaluation of abilities, as well as completely subconscious prejudices, distort the image at evaluating one's own child's possibilities (Simeunović and Milic, 2013). While evaluating the giftedness of their own children, parents do not have a possibility to compare their achievements with those of other children (Sommer et al., 2008).

Considering the time students of one class spend together, along with the fact that they constantly compare their own results with those of other students, coevals of gifted students can provide us with the information as to who solves difficult tasks most easily and quickly, who has the most of new ideas, who tells most beautiful tales, who invents best games, who always wins, who draws, paints or models most beautifully, who plays jokes most, and who they like to be friends with. Students who have been noticed as talented for mathematics and sciences are different from their average coevals the way that the talented ones organise their free time around the areas which they are talented for, either by directly trying to learn more and deal with that field or by working on general development (Maksić and Tenjović, 2008).

Gardner (1993) points out that the most important precondition for a reliable evaluation is observing the way parents manipulate with symbolic systems of each type of intelligence. The problem of discrepancy between teacher's and parent's evaluation is likely to be the very lack of knowledge on these symbolic systems. A teacher has the possibility of comparing the students, but parents also have enough time and only one child who they need to observe, i.e. their ways of solving problems and shaping products in real life contexts.

\section{Difficulties and Constraints in the Process of Identifying the Giftedness}

The complexity and enormous significance of the process of early identification of giftedness as itself, imply a number of problems and constraints which those responsible for end results encounter. It is certainly simpler to identify giftedness later, during the period of secondary education, even with subject teaching rather than class teaching. At their later development, students become fully aware of their strengths, virtue and power, further on they have a developed system of values which serves them to find their own place in social environment, but their creative products are also visible, possibly already confirmed by a public recognition, a reward or through another method of promotion.

The complexity of the identification process and difficulties encountered during the planning and implementation procedures lead to two directions. The first problems emerge at the very beginning and they are relevant to selection of procedures and instruments for evaluation of giftedness, as well as to drawing a line between giftedness and non-giftedness. The second group of problems relates to selection of students to be involved in the procedure, along with psychological and physical factors affecting the students at examination.

The issue of identifying the giftedness reaches its climax in the point of defining the limit between giftedness and non-giftedness. At the same time, this issue not only has an ethical dimension but it is fundamental in determination of each individual's "under microscope" fate. Even when best quality multidisciplinary approach during the identification is ensured, there is the issue of who is the student to draw the line after and characterise all of the students beyond the line as those who really do not have the gift. These errors are certainly two-sided untalented students can be declared talented, but also talented ones can be declared untalented. The first case bears a lot fewer harmful consequences, either for the individual or for the community. Even when the criteria are made lower, the second error can be avoided, but the identification considerably loses its meaning.

To deal with this issue at all, teachers and all of those who work on identification of gifted students must certainly have a broad scope of theoretical knowledge on the phenomenon of giftedness, i.e. they must know that there are various types of giftedness and various ways of their manifestation, then learn to differ certain terms which are closely connected but still define different things, and recognise the characteristics and development needs of gifted students. There is certainly little chance that a student with above average and brilliant academic results is neglected in the selection of students for the identification process. The same applies to those students whose nature is to be self-assertive and free in expressing their thoughts or showing and boasting about products 
of their work. Major problem is with students whose gifted potential is hidden deeply in them, but which cannot be distinguished or shaped as giftedness due to other components of their personality. Such potentials most frequently remain unnoticed in students with a physical handicap, in those who are not able to fit in their social environment, and in those who have learning difficulties.

\section{Conclusions}

The idea of structuring the instruments to be applied by four different evaluators in identifying potentially high abilities included in nine types of intelligence according to Gardner's Theory has resulted from scientific, economic and practical needs and causes. The first need is based on results of relevant literature researches pointing out the multidisciplinary approach to the identification of giftedness (Wild, 1991; Heller et al., 2005) along with reduction of type I and type II errors. In the course of studying the literature, there has been noticed that the Republic of Srpska had only few studies dealing with innovations in the teaching process with gifted students (Simeunović and Milić, 2014) and it was confirmed as necessary to carry out a scientific research to contribute to improvement of the theory and methodology of studying the phenomenon of giftedness.

The second reason is that the instruments are simple for use and can be used whenever there is a need for it. The instruments are not time-consuming for evaluators either, and they can be applied separately in quantifying each intelligence type individually, but evaluators do not necessarily apply them simultaneously. Since the instruments have been structured in the form of scales, their production is very economical, which provides for a frequent use thereof, including evaluation of abilities of students who are not gifted. In addition to their primary use, the tests can serve to examine other psychological-pedagogical and didactic-methodical occurrences (e.g. teacher's competence to work with the gifted). Further on, it will be possible in the future to examine the influence and interconnection of other categories (motivation, self-concept, social-economic circumstances) with the evaluations, and to determine the reasons for errors occurring in the course of evaluation.

Based upon a scientific inspection of the research results obtained, the conclusion was that it is justifiable to identify logical-mathematical giftedness in young primary school students through the evaluation. In an attempt to deal with the issue of identifying the giftedness from as many aspects as possible, new methodological solutions have been developed and implemented.

The initial hypothesis of existence of co-ordinance amongst evaluations of selected students' abilities, done by four evaluator groups: teachers, parents, coevals and students; has been confirmed. The results presented show that teachers evaluated the logical-mathematical abilities highest. Teachers' evaluations are followed, according to the level of scores, by students' own evaluations, then by coevals' evaluations, whereas parents' evaluations were the lowest. Statistically relevant differences between four $\mathrm{a} / \mathrm{m}$ evaluator groups were found, whereupon the exact differences were determined. Namely, highest-level co-ordinance was found among teacher and student evaluations, whereas the only statistically relevant difference was found with teacher and parent evaluations.

The issue relevant to innovation of teaching approach in the work with gifted students starts from the way state institutions treat gifted students, which reflects on all the remaining educational facilities, including plans and curricula, primarily those who educate and raise them, then the curricula of those being educated and raised. It is also necessary to educate parents to recognise and follow the development and interests of their children. To achieve a successful development of giftedness and provide an adequate support, all of the factors included in direct and indirect dealing with gifted students, i.e. gifted individuals, parents, guardians and family, those in charge of education, local community and Republic bodies in charge of development of education, need to act in a synergy.

Evaluations of giftedness obtained through this research will serve as a basis for individual testing and comparing these results to other evaluations, all of this aiming to adequately form instruments for good quality identification of gifted students. For further research of giftedness, assessments made by individuals who work with or are in a position to characterise a student as gifted are very important. Such work opens a space for establishing a database on evaluations of students' abilities, in order to move on to a next step which is creation of a predictive model based on likelihood and expectations as to possible identification of giftedness.

\section{References}

Aljughaiman, A. and I. Usama, 2009. Behavioural characteristics rating scale development and validating a behavioural characteristics rating scale of kindergarten gifted children in Saudi Arabia. Asia-Pacific Journal of Gifted and Talented Education, 1(1): 87-103. View at Google Scholar

Biro, M., 1997. Priručnik za REVISK. Beograd: Društvo psihologa Srbije.

Bordelon, D.E. and M.M. Banbury, 2005. Pursuing the parameters: Validating the multiple intelligences inventory for teachers. Assessment for Effective Intervention, 30(3): 33-51. View at Google Scholar | View at Publisher

Borland, J.H., 1989. Plarming and implementing programs for the gifted educaticrn and psychology of the gifteel series. New York: Teachers College Press.

Callahan, C.M., C.A. Tomlinson, S.L. Hunsaker, L.C. Bland and T. Moon, 1995. Instruments and evaluation designs used in gifted programs. Storrs, CT: The National Research Center on the Gifted and Talented.

Chan, D., 2007. Assessing multiple intelligences of Chinese gifted students in Hong Kong: Self-perceived abilities, preferences, and intelligence-related activities. Gifted and Talented, 11:18-25.

Dai, D.Y., J.A. Swanson and H. Cheng, 2011. State of research on giftedness and gifted education: A survey of empirical studies published during 1998-2010. Gifted Child Quarterly, 55(2): 126-138. View at Google Scholar | View at Publisher

Davis, G. and S. Rimm, 2004. Education of the gifted and talented. 5th Edn., Boston: Allyn \& Bacon.

Đorđević, B., 1998. Gifted students and failure at school. Belgrade: Faculty of Teacher Education.

Dweck, C.S. and E.L. Leggett, 1988. A social-cognitive approach to motivation and personality. Psychological Review, $95(2): 256-273$. View at Google Scholar | View at Publisher

Feldhusen, J.F., S.M. Hoover and M.F. Sayler, 1990. Identifying and educating gifted students at the secondary level. Monroe, NY: Trillium Press.

Freeman, J., 2005. Permission to be gifted: How conceptions of giftedness can change lives. In Sternberg R., Davidson J. (Eds.), Conceptions of giftedness. Cambridge, UK: Cambridge University Press. pp: 80-97.

Gardner, H., 1985. Frames of mind: The theory of multiple intelligence. New York: Basic Books, Inc. Publishers.

Gardner, H., 1993. Multiple intelligence, the theory in practice. New York: Basic Books.

Gardner, H., 1999. Intelligence reframed: Multiple intelligences for the 21 st century. New York: Basic Books.

Gardner, H., 2003. Multiple intelligences after twenty years. Paper Presented at the Annual Meeting of the American Educational Research Association, Chicago. 
Gardner, H., 2006. Multiple intelligences: New horizons. New York: Basic Books.

Gear, G.H., 1976. Accuracy of teacher judgment in identifying intellectually gifted children: A review of the literature. Gifted Child Quarterly, 20(4): 478-490. View at Google Scholar | View at Publisher

George, D., 2005. Obrazovanje darovitih: Kako identificirati i obrazovati darovite i talentirane učenike. Zagreb: Educa.

Han, K.S. and C. Marvin, 2000. A five year follow-up study of the Nebraska project. Roeper Review, 23(1): 25-33. View at Google Scholar | View at

Publisher
Heller, K.A., R. Reimann and A. Senfter, 2005. Hochbegabung im Grundschulalter: Erkennen und Fördern [Giftedness in elementary school: Assessing and encouraging] Münster: Lit.

Hernández-Torrano, D., 2014. The theory of multiple intelligences in the identification of high-ability students. Anales de Psicología, 30(1): $192-200$.

Lubart, T.I., 1994. Thinking and problem solving. New York: Akademik Press.

Maksić, S. and L. Tenjović, 2008. Linkage between interests and verbal fluency of primary school pupils. Psyhology, 41(3): 311-325. View at Google Scholar | View at Publisher

McBee, M.T., S.J. Peters and C. Waterman, 2014. Combining scores in multiple-criteria assessment systems: The impact of combination rule. Gifted Child Quarterly, 58(1): 69 - 89. View at Google Scholar

McBride, N., 1992. Early identification of the gifted and talented students: Where do teachers stand? Gifted Education International, 8(1): 19-22. View at Google Scholar | View at Publisher

Mezö, F., 2008. Psychological aspects of gifted education. University of Debrecen.

Simeunović, V. and S. Milic, 2013. Gifted pupils in primary school - support and development. Banja Luka: EKTA.

Simeunović, V. and S. Milić, 2014. Identifikacija darovitosti kod učenika nižih razreda osnovne škole putem procjene. Zbornika Radova sa Naučnog Skupa 14. Dani Mate Demarina, Učiteljski Fakultet Zagreb: 263 - 273.

Sommer, U., A. Fink and A. Neubauer, 2008. Detection of high ability children by teachers and parents: Psychometric quality of new rating checklists for the assessment of intellectual, creative and social ability. Psychology Science Quarterly, 50(2): 189 - 205. View at Google Scholar

Tirri, K. and P. Nokelainen, 2008. Identification of multiple intelligences with the multiple intelligence profiling questionnaire III. Psychology Science Quarterly, 50(2): 206 -22 1. View at Google Scholar

Wild, K.P., 1991. Identifikation hochbegabter Schüler. Lehrer und Schüler als Datenquellen ¿Identification of gifted pupils. Teachers and pupils as data resources]. Heidelberg: Roland Asanger. 